\title{
Pendeteksian Kecurangan Pelaporan Keuangan Dengan Menggunakan Pentagon Fraud Pada BUMN Yang Terdaftar Di Bursa Efek Indonesia
}

\author{
Ni Putu Gina Puspita Dewi dan I Gede Agus Pertama Yudantara²
}

\author{
Program Studi S1 Akuntansi, Universitas Pendidikan Ganesha \\ Singaraja, Indonesia \\ e-mail: ${ }^{1}$ ginapuspita.dewi04@gmail.com , ${ }^{2}$ | agus.yudantara@undiksha.ac.id
}

\begin{abstract}
Abstrak
Penelitian ini memiliki tujuan untuk menganalisis pengaruh variabel tekanan, peluang, rasionalsiasi, kompetensi dan arogansi baik secara simultan dan parsial dalam pendeteksian kecurangan pelaporan keuangan. Data yang dipakai yakni data sekunder berupa laporan tahunan serta laporan keuangan BUMN yang terdaftar di BEI periode 2014-2018. Teknik memilih sampel memakai purposive sampling sehigga memperoleh sampel berjumlah 17 BUMN. Analisis data yang dipakai yakni statistik deskriptif dan analisis regresi logistik dengan program SPSS 20. Hasil penelitian ini menyatakan bahwa secara simultan tekanan, peluang, rasionalisasi, kompetensi dan arogansi berpengaruh signifikan dalam pendeteksian kecurangan pelaporan keuangan. Hasil pengujian secara parsial menujukkan bahwa frekuensi jumlah foto CEO yang menjadi proksi variabel arogansi berpengaruh positif signifikan, variabel tekanan (Rasio leverage) berpengaruh negatif signifikan, sedangkan peluang (persentase jumlah komite audit independen), rasionalisasi (pergantian akuntan publik) serta kompetensi (pergantian direksi) tidak berpengaruh dalam pendeteksian kecurangan pelaporan keuangan.
\end{abstract}

Kata kunci : Pentagon fraud, kecurangan pelaporan keuangan

Abstract
This study aimed at analyzing the effects of pressure, opportunity, rationalization, competence and arrogance both concurrently and relatively on fraudulent financial reporting on state-owned companies registered on the Indonesia Stock Exchange in the 2014-2018 period. The secondary data acquired from yearly reports and financial statements of the state-owned companies listed on the Stock Exchange in the 2014-2018 period were applied in this study. The sample representative method used purposive sampling so that 17 companies were used in this study. Data analysis method used in this study were descriptive statistical analysis and logistic regression analysis using SPSS 20. The results of this study convey the simultaneous the pressure, the opportunity, the rationalization, the competence, and the arrogance influence the detection of fraudulent financial reporting notably. The trial results partially indicate that arrogance which is substituted by the frequency of the number of CEO photos has a significant positive outcome in distinguishing fraudulent financial reporting, while the pressure variable (leverage ratio), the opportunity (percentage of the number of independent audit board), the rationalization (change of public accountants) and the competence (changes directors) partially has no effect in the detection of fraudulent financial reporting.

Keyword : Pentagon fraud, fraudulent financial reporting.

\section{Pendahuluan}

Laporan keuangan perusahaan yang memuat informasi tentang neraca, laba rugi, perubahan modal, arus neraca dan juga CALK pada periode tertentu yang bisa digunakan pemakai laporan keuangan untuk membuat kebijakan, hal ini lah salah satu bentuk akuntabilitas yang disediakan oleh manajemen. Tujuan laporan keuangan yakni menjadi media penyedia informasi yang dapat dipakai oleh investor dan kreditur pada saat pengambilan keputusan investasi dan pemberian kredit kepada perusahaan secara rasional (FASB,1978). Di Perusahaan laporan keuangan memiliki peran yang sangat krusial karena 
itu manajemen berupaya untuk menyusun laporan keuangan secara akurat dan relevan sehingga memberikan gambaran kinerja yang baik untuk perusahaan.

Fraudulent statement merupakan tindakan kecurangan pelaporan keuangan yang dimana seseorang secara sengaja melakukan penyembunyian (omission) atau melakukan kekeliriuan dalam penyajian (misstatement) yang dipakai guna megecoh pemakai laporan keuangan. Kecurangan pelaporan keuangan terjadi disebabkan oleh manajemen yang mempunyai tugas untuk menyusun laporan keuangan secara sengaja melakukan kecurangan yang dapat menyebabkan terjadinya salah saji material di laporan keuangan perusahaan (Annisya dkk, 2016). Ak dkk. (2013) mengatakan bahwa F-score adalah metode penelitian terkait risiko kecurangan pelaporan keuangan yang memiliki nilai akurasi yang tinggi sehingga metode ini baik untuk digunakan dalam pendeteksian kecurangan pelaporan keuangan.

Badan Usaha Milik Negara merupakan organisasi pemerintah yang berada di bawah naungan Kementrian BUMN Republik Indonesia. Berdasarkan hasil penelitian Association of Certified Fraud Examinier tahun 2016 di Indonesia, lembaga yang paling dirugikan akibat fraud adalah $81,2 \%$ berasal dari lembaga pemerintah, kemudian $8,1 \%$ berasal dari lembaga perusahaan negara atau BUMN dan 2,3\% berasal dari Lembaga swasta, sedangkan untuk sektor industri yang paling dirugikan akibat fraud yakni $58,8 \%$ berasal dari perusahaanperusahaan yang berstatus BUMN (ACFE Indonesia, 2016).

Menurut data yang terdapat pada situs Kementrian BUMN pada tahun 2020, terdapat 115 perusahaan negara yang menjadi milik Kementrian BUMN yang terbagi menjadi 96 badan usaha yang tidak terdaftar dan 20 BUMN yang terdaftar di BEI (Kementrian BUMN, 2020). Sumber modal dari BUMN yang terdaftar di BEI berasal dari suntikan dana pemerintah dan investasi yang dilakukan oleh stakeholder yang dimana pemerintah dan stakeholder mengharapkan adanya keuntungan dari modal yang mereka berikan berupa laba dan deviden. Apabila kinerja yang dimiliki BUMN melemah secara terus menerus, maka akan memberikan dampak pada pendapatan yang menurun setiap tahunnya, sehingga untuk menjalankan aktivitas operasional badan usaha membutuhkan dana ekstra, baik yang bersumber dari dana pemerintah dan stakeholder itu sendiri maupun pinjaman utang dari kreditur. Pemerintah dan stakeholder akan memberikan dana apabila kinerja badan usaha dalam keadaan yang baik, hal tersebut akhirnya menyebabkan banyak BUMN yang melaksanakan kecurangan yang bertujuan agar kinerja keuangan perusahaan yang ada di laporan keuangan terlihat dalam keadaan yang baik, sehingga pemerintah dan stakeholder tetap memberikan suntikan dana dan percaya terhadap kinerja badan usaha tersebut.

Thohir (2020) menyatakan bahwa saat ini sering terjadi manipulasi laporan keuangan atau window dressing pada BUMN. Badan Usaha seolah-olah meraih keuntungan tetapi nyatanya tidak memiliki dana sesuai dengan apa yang mereka laporkan pada laporan keuangan. Kasus kecurangan pelaporan keuangan di BUMN yang banyak diperbincangkan adalah kasus kecurangan yang dilakukan oleh Garuda Indonesia tahun 2018. Kantor akuntan publik yang saat itu memiliki tugas untuk mengaudit laporan keuangan terlibat dalam praktik kecurangan yang perusahaan lakukan. Dampaknya adalah akuntan publik tersebut memperoleh sanksi dari Menteri Keuangan yakni pembekuan izin selama satu tahun. Selain itu susunan direksi serta komisaris yang terlibat pada kasus ini juga mendapatkan sanksi dari OJK dan BEI (Hartomo, 2019). Kasus lainnya dilakukan oleh PT Timah tahun 2015, Indofarma tahun 2001 dan Kimia Farma tahun 2001. Kasus-kasus yang pernah terjadi tersebut tentu dapat mencoreng citra baik yang dimiliki badan usaha itu sendiri maupun pemerintah yang gagal untuk mengawasi kinerja BUMN.

Teori pentagon fraud yang dikembangkan oleh marks pada tahun 2012 adalah salah satu teori yang dapat dipakai dalam pendeteksian kecurang pelaporan keuangan. Teori ini terdiri lima faktor penyebab terjadinya kecurangan yakni tekanan, peluang, rasionalisasi, kompetensi serta arogansi.

Menurut Wardhani (2018) Suatu dorongan yang disebabkan oleh suatu kondisi yang dimiliki seseorang untuk melakukan kecurangan pada pentagon fraud disebut dengan faktor tekanan. Kecurangan pelaporan keuangan dapat terjadi menurut American Institute of Certified Publik Accountant (2002) dikarenakan manajemen perusahaan memperoleh 
tekanan dari pihak eksternal yang mendorongnya untuk melakukan kecurangan yang dapat disebabkan oleh keadaan ekonomi, industri serta siatuasi lainnya.

Ketika perusahaan sedang dalam keadaan ekonomi yang terancam manajer akan berupaya untuk menutupi keadaan ekonomi perusahaan dengan cara melakukan pinjaman kredit (hutang) pada bank, pihak ketiga maupun pihak lainnya. Pada saat manajemen perusahaan melakukan pinjaman kredit maka akan berdampak pada rasio leverage yang semakin meningkat. Rasio leverage yakni kapasitas perusahaan untuk membayar semua utang perusahaan dengan memakai semua asset perusahaan. Ketika perusahaan mempunyai hutang yang semakin meningkat, maka rasio leverage juga semakin meningkat yang menyebabkan risiko kredit perusahaan juga juga semakin tinggi. Apabila perusahaan mengalami kerugian yang besar biasanya untuk menutupi hal tersebut perusahaan akan melakuakan kecurangan pelaporan keuangan sehingga kinerja perusahaan akan terlihat dalam kondisi yang baik sehingga pemerintah dan stakeholder tetap percaya terhadap kinerja perusahaan (Agustina dan Pratomo, 2019). Penelitian oleh oleh Rusmana dan Tanjung (2019), serta Tessa dan Harto (2016) menujukkan bahwa secara parsial rasio leverage yang merupakan proksi variabel tekanan berpengaruh positif signifikan dalam pendeteksian kecurangan pelaporan keuangan.

$\mathrm{H}_{1}$ : Tekanan berpengaruh positif dalam pendeteksian kecurangan pelaporan keuangan.

Menurut Wardhani (2018) Suatu kejadian yang menyebabkan seseorang untuk melaksanakan fraud di suatu perusahaan disebut dengan faktor peluang. Public Company Accounting Oversight (2017) mengungkapkan bahwa peluang dapat muncul dikarenakan adanya andil dari komite audit atas ketidakefektifan pengawasan. Komite audit independen perusahaan bersumber dari pihak luar. Ketidakefektifan pengawasan komite audit independen di perusahaan dapat terjadi dikarenakan terbatasnya pengetahuan yang mereka miliki terkait bisnis yang dikelola perusahaan, selain itu kemungkinan mereka mempunyai tanggungjawab yang sama di perusahaan yang lain, sehingga dapat meningkatkan terbukanya peluang bagi manajemen perusahaan untuk melakukan kecurangan (Alwi, dkk., 2014). Ketidakefektifan pengawasan yang dilakukan komite audit independen akan memberikan peluang yang semakin besar kepada perusahaan dalam melakukan manipulasi laporan keuangan (Harahap dkk, 2017). Penelitian oleh Agustina dan Pratomo (2019 dan Alwi, dkk. (2014) menyatakan bahwa secara parsial persentase jumlah komite audit independen yang merupakan proksi variabel peluang berpengaruh positif signifikan dalam pendeteksian kecurangan pelaporan keuangan.

$\mathrm{H}_{2}$ : Peluang berpengaruh positif dalam pendeteksian kecurangan pelaporan keuangan.

Rasionalisasi adalah sikap pembenaran yang timbul pada pikiran manajemen perusahaan saat kecurangan pelaporan keuangan sudah terjadi pada perusahaan. Pikiran ini akan timbul disebabkan manajemen perusahaan tidak ingin perbuatan kecurangan pelaporan keuangan yang sudah dilakukannya diketahui oleh akuntan publik, sehingga manajemen perusahaan membetulkan kecurangan yang telah mereka laksanakan. Pada perusahaan, tugas untuk mengawasi serta memeriksa laporan keuangan yang sudah selesai disusun perusahaan dilakukan oleh akuntan publik. Perusahaan yang terlibat kecurangan pelaporan keuangan umumnya lebih sering untuk melakukan pergantian akuntan publik dengan tujuan untuk memperkecil kemungkinan pendeteksian oleh akuntan publik yang lama dengan anggapan bahwa akuntan publik yang baru belum memahami keadaan perusaaan dengan baik dan sebagai bentuk usaha perusahaan untuk menghapus jejak (fraud trail) kecurangan yang diperoleh auditor sebelumnya (Wardhani, 2018. Tessa dan Harto 2016. dan Siddiq, dkk. 2017). Penelitian oleh Siddiq, dkk. (2017) dan Noorjamil (2019) yang menyatakan bahwa secara parsial pergantian akuntan publik yang merupakan proksi variabel rasionalisasi berpengaruh positif signifikan dalam pendeteksian kecurangan pelaporan keuangan.

$\mathrm{H}_{3}$ : Rasionalisai berpengaruh positif dalam pendeteksian kecurangan pelaporan keuangan. 
Seseorang yang mempunyai kemampuan untuk melakukan kecurangan pelaporan keuangan pada pentagon fraud disebut dengan faktor kompetesi, dimana sifat ini dapat menyebabkan manajemen perusahaan (agen) lebih mementingkan dirinya sediri (self interest) dari pada memaksimalkan kepentingan principals (Trisnaningsih, 2019). Pergantian direksi dapat dinilai mampu untuk memberikan gambaran mengenai kompetensi yang dimiliki oleh direksi dalam melakukan manejemen stress (stress period) sehingga dapat menyebabkan semakin besarnya peluang manajemen perusahaan untuk terlibat kecurangan pelaporan keuangan (Wardhani, 2018). Pergantian direksi juga dilakukan sebagai upaya perusahaan untuk mengurang evektivitas dari kinerja manajemen, hal ini dikarenakan manajemen membutuhkan periode yang lebih lama agar dapat menyesuaikan diri dengan kinerja serta kebiasaan dari direksi yang baru (Septiani dan Handayanti, 2018). Penelitian oleh Manurung dan Hardika (2015) dan Noorjamil (2019) menyatakan bahwa secara parsial pergantian direksi yang merupakan proksi variabel kompentensi berpengaruh positif signifikan dalam pendeteksian kecurangan pelaporan keuangan.

$\mathrm{H}_{4}$ : Kompetensi berpengaruh positif dalam pendeteksian kecurangan pelaporan keuangan.

Arogansi adalah sifat congkak atau sombong yang dimiliki seseorang yang menganggap bahwa dirinya mempunyai kemampuan untuk melakukan tindakan fraud. Sifat arogansi pada seorang CEO (agen) dapat timbul dikarenakan CEO mempunyai sifat self interest yang besar dimana CEO akan lebih mendahului kepentingan diri sendiri dari pada memaksimalkan kepentingan principals. Sifat arogansi CEO yan tinggi dapat menyebabkan kecurangan pelaporan keuangan dapat terjadi, hal tersebut dikarenakan CEO yang mempunyai arogansi yang tinggi dapat menyebabkanya melakukan berbagai cara untuk melindungi status, kedudukan serta jabatan yang dimilikinya, salah satunya dengan melakukan kecurangan pelaporan keuangan. CEO yang tidak mau untuk kehilangan jabatan serta status yang dimiliknya biasanya akan lebih sering menujukkan kepada publik terkait jabatan serta status yang mereka miliki di laporan tahunan (Septriani dan Handayani, 2018). Penelitian oleh Tessa dan Harto (2016) dan Noorjamil (2019) mengatakan bahwa secara parsial frekuensi jumlah foto CEO merupakan proksi variabel arogansi berpengaruh positif signifikan dalam pendeteksian kecurangan pelaporan keuangan.

$\mathrm{H}_{5}$ : Arogansi berpengaruh positif dalam pendeteksian kecurangan pelaporan keuangan.

Crowe (2011) dalam Teori Pentagon Fraud menjelaskan bahwa tekanan, peluang, rasionalisasi, kompetensi dan arogansi adalah faktor yang dapat berpengaruh dalam pendeteksian kecurangan. Teori pentagon fraud merupakan pengembangan dari teori triangle fraud. Semakin tinggi pengaruh faktor-faktor yang terdapat dalam pentagon fraud, maka semakin tinggi juga kecurangan pelaporan keuangan perusahaan (Noorjamil, 2019). Pada penelitian Agustina dan Pratono (2019) dan Aprilia (2017) mendapatkan hasil jika secara simultan lima faktor yang terdapat pada teori pentagon fraud.

$\mathrm{H}_{6}$ : Tekanan, kesempatan, rasionalisasi, kemampuan dan arogansi secara simultan berpengaruh dalam pendeteksian kecurangan pelaporan keuangan.

\section{Metode}

Penelitian ini memakai populasi sebanyak 20 BUMN yang terdaftar di BEI. Metode memilih sampel di penelitian ini adalah purposive sampling dengan kriteria sebagai berikut; BUMN yang terdaftar di BEI tahun 2014-2018 yang mempublikasikan laporan keuangan dan laporan tahunan yang sudah di audit dalam bentuk rupiah (Rp), serta mempunyai kelengkapan data yang diperlukan terkait variabel penelitian. Adapun jumlah BUMN yang sesuai dengan kriteria diatas berjumlah 17, dimana 3 BUMN tidak termasuk ke dalam sampel karena laporan keuangan perusahaan sampel yang dipublikasi dengan mata uang dollar Amerika. Penelitian ini termasuk penelitian kuantitafif dengan memakai data sekunder yaitu laporan tahunan dan laporan keuangan yang diperoleh dari situs web BEI dan perusahaan yang diuji dan dianalisis dengan memakai statistik deskriptif dan analisis regresi logistik dengan program SPSS 20. 


\section{Hasil Dan Pembahasan}

Tabel 1. Hasil Analisis Statistik Deskriptif Data Numerik

\begin{tabular}{lccc}
\hline & Rasio Leverage & $\begin{array}{c}\text { Persentase Jumlah Komite } \\
\text { Audit Independen }\end{array}$ & $\begin{array}{c}\text { Frekuensi Jumlah Foto } \\
\text { CEO }\end{array}$ \\
\hline $\mathrm{N}$ & 85 & 85 & 85 \\
Mean & 0,6099 & 0,8923 & 9,46 \\
Std Deviation & 0,20574 & 0,13545 & 2,343 \\
Minimum & 0,08 & 0,50 & 4 \\
Maximum & 0,92 & 1,00 & 15 \\
\hline
\end{tabular}

Tabel 2. Hasil Analisis Statistik Deskriptif Data Katagorial

\begin{tabular}{|c|c|c|c|c|}
\hline & & Frequency & Percent & $\begin{array}{l}\text { Cumulative } \\
\text { Percent }\end{array}$ \\
\hline \multirow{2}{*}{$\begin{array}{l}\text { Pergantian } \\
\text { Direksi }\end{array}$} & $\begin{array}{l}\text { Tidak } \text { Melakukan } \text { Pergantian Akuntan } \\
\text { Publik }\end{array}$ & 44 & 51,8 & 51,8 \\
\hline & Melakukan Pergantian Akuntan Publik & 41 & 48,2 & 100 \\
\hline $\begin{array}{l}\text { Pergantian } \\
\text { Akuntan } \\
\text { Publik }\end{array}$ & $\begin{array}{l}\text { Tidak Melakukan Pergantian Direksi } \\
\text { Melakukan Pergantian Direksi }\end{array}$ & $\begin{array}{l}60 \\
25\end{array}$ & $\begin{array}{l}70,6 \\
29,4\end{array}$ & $\begin{array}{l}70,6 \\
100\end{array}$ \\
\hline \multirow{2}{*}{$\begin{array}{l}\text { Kecurangan } \\
\text { Pelaporan } \\
\text { Keuangan }\end{array}$} & $\begin{array}{l}\text { Tidak Terindikasi Melakukan Kecurangan } \\
\text { Pelaporan Keuangan }\end{array}$ & 76 & 89,4 & 89,4 \\
\hline & $\begin{array}{l}\text { Terindikasi Melakukan } \\
\text { Pelaporan Keuangan }\end{array}$ & 9 & 10,6 & 100 \\
\hline
\end{tabular}

Tabel 3. Perbandingan Nilai -2LL Awal dengan -2LL

\begin{tabular}{ccc}
\hline Block Number $=0$ & Block Number $=1$ & Penurunan/Kenaikan \\
\hline 55,429 & 40,906 & Penurunan \\
\hline
\end{tabular}

Di tabel 3, nilai -2LL awal 57,429 > -2LL akhir 40,906, dapat dikatakan bahwa terjadi penurunan nilai -2LL yang artinya konstanta yang menggunakan lima variabel independen sebagai model dapat dipakai untuk menjelaskan pengaruhnya terdapat pendeteksian kecurangan pelaporan keuangan. Penurunan nilai $-2 L L$ menyatakan pengujian mengarah pada bentuk model yang cocok.

Tabel 4. Omnibus Test of Model Coefficients

\begin{tabular}{|c|c|c|c|c|}
\hline & & Chi-square & $\mathrm{Df}$ & Sig. \\
\hline \multirow[t]{3}{*}{ Step 1} & Step & 16,523 & 5 & 0,005 \\
\hline & Block & 16,523 & 5 & 0,005 \\
\hline & Model & 16,523 & 5 & 0,005 \\
\hline
\end{tabular}

Sumber : Data yang diolah peneliti, 2020

Di tabel 4, nilai Chi Square 16,523 > Chi Square tabel pada DF 5 yaitu 11,07050, serta nilai signifikansi $0,005<0,05$. Hasil ini menyatakan bahwa variabel independen yang ditambahkan ke model DAPAT memberikan pengaruh yang nyata pada model yang dipakai, atau bisa disimpulan bahwa model dikatakan cocok.

Tabel 5. Model Summary

\begin{tabular}{cccc}
\hline Step & -2 Log likelihood & Cox \& Snell $R$ Square & Nagelkerke $R$ Square \\
\hline 1 & 40,906 & 0,177 & 0,360 \\
\hline
\end{tabular}

Di tabel 5, nilai Nagelkerke $R$ Square sebesar 0,360 dan nilai Cox \& Snell $R$ Square sebesar 0,177, yang menyatakan bahwa variabel independen mempunyai kemampuan untuk menjelaskan variabel dependen kecurangan pelaporan keuangan sebesar 0,360 (36\%) dan faktor lain di luar model sebesar 64\%. 
Tabel 6. Hosmer and Lemeshow Test

\begin{tabular}{cccc}
\hline Step & Chi Square & df & Sig. \\
\hline 1 & 2,593 & 7 & 0,92 \\
\hline
\end{tabular}

Sumber : Data yang diolah peneliti, 2020.

Di tabel 6, nilai Chi Square sebesar 2,593 dan nilai signifikansi sebesar 0,920>0,05 sehingga $\mathrm{H}_{0}$ diterima. Maka bisa dikatakan bahwa analisis selanjutnya dapat dilakukan, karena model regresi pada penelitian ini layak untuk dipakai. Hal ini dikarenakan model regresi dengan nilai observasinya tidak mempunyai perbedaan yang signifikan, sehingga dapat dikatakan model regresi cocok dengan data.

Tabel 7. Classification Table

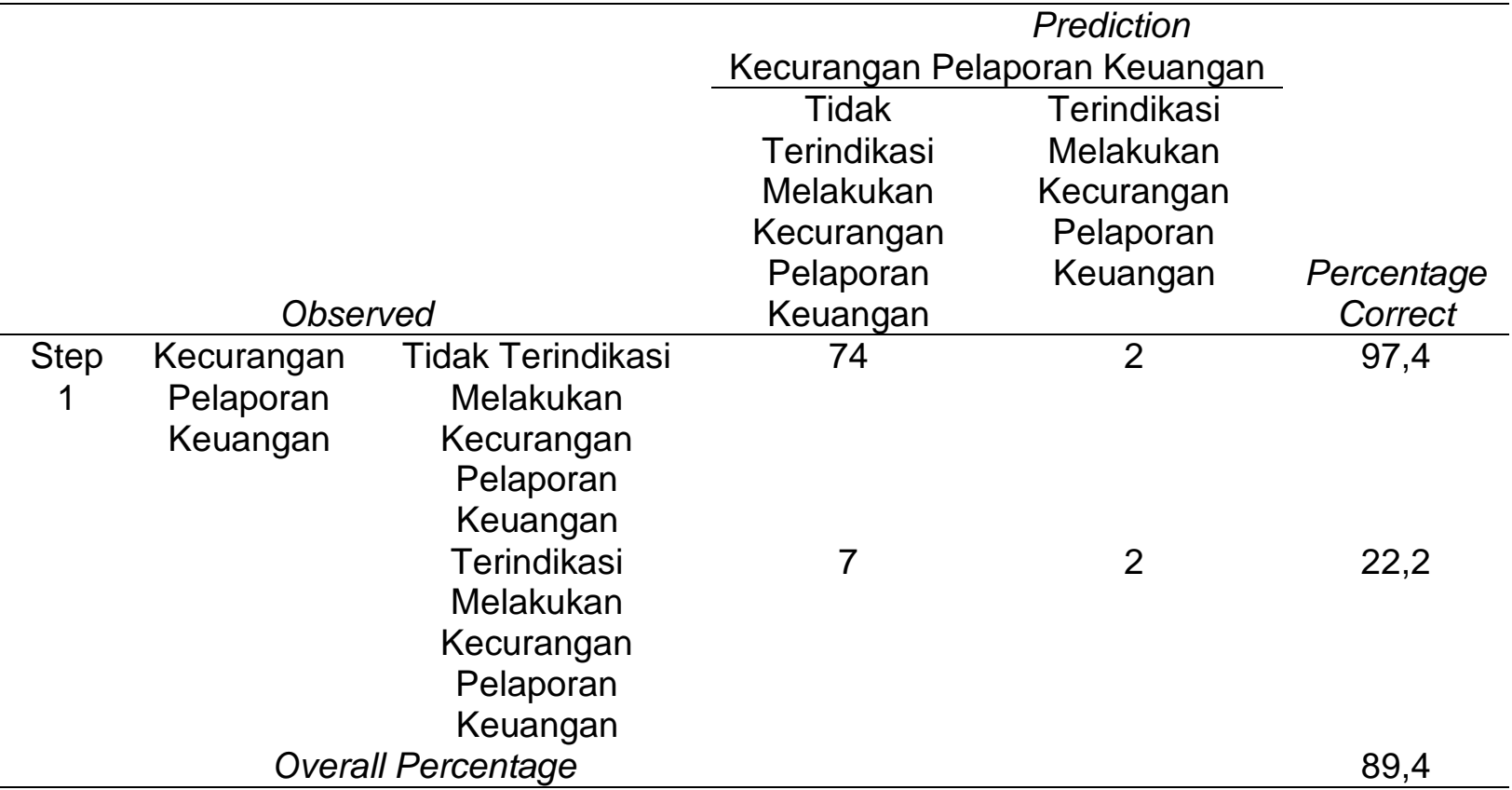

Di tabel 7, dari 76 sampel penelitian yang di prediksi, 74 sampel diprediksi tidak terindikasi melakukan kecurangan pelaporan keuangan atau sebesat 97,4\% dan 2 sampel lainnya gagal diprediksi. Selanjutnya, dari 9 sampel yang diprediksi, sebanyak 7 sampel terindikasi melakukan kecurangan pelaporan keuangan atau sebesar 22,2\% dan 2 sampel lainnya gagal diprediksi. Nilai overall percentage sebesar $(74+2) / 85=89,4 \%$ yang berarti nilai ketepatan model penelitian yaitu sebesar $89,4 \%$.

Tabel 8. Hasil Regresi Logistik

\begin{tabular}{lcccc}
\hline \multicolumn{1}{c}{ Variabel } & Prediksi Arah & Nomor Hipotesis & Koefisien & Signifikansi \\
\hline Tekanan & + & 1 & $-6,433$ & 0,009 \\
Peluang & + & 2 & 0,336 & 0,913 \\
Rasionalisasi & + & 3 & $-0,938$ & 0,309 \\
Kompetensi & + & 4 & $-1,634$ & 0,165 \\
Arogansi & + & 5 & 0,613 & 0,031 \\
Simultan & & 6 & 16,523 & 0,005 \\
\hline
\end{tabular}

\section{Pengaruh Tekanan Dalam Pendeteksian Kecurangan Pelaporan Keuangan}

Pada tabel 8, nilai signifikansi variabel $\mathrm{X}_{1}$ sebesar $0,009<0,05$ dan nilai koefisien regresi sebesar $-6,433$. Hasil ini sejalan dengan penelitian terdahulu yaitu oleh sulastri (2019) yang menujukkan bahwa secara parsial rasio leverag yang merupakan proksi variabel tekanan berpengaruh negatif signifikan dalam pendeteksian kecurangan pelaporan keuangan. 
Hal tersebut dikarenakan saat rasio leverage perusahaan meningkat, maka dapat menyebabkan perusahan mengalami tekanan yang semakin besar yang dapat menyebabkan kreditur melakukan pengawasan secara ketat terkait siklus utang perusahaan, sehingga fleksibilitas perusahaan untuk melakukan kecurangan pelaporan keuangan menurun (Septiarini dan Handayani, 2018). Rasio leverage tidak dapat dipakai pada pendeteksian kecurangan pelaporan keuangan pada perusahaan sampel dikarenakan sebagian besar hutang yang dimiiliki oleh perusahaan sampel diperoleh dari pihak ketiga yang mempunyai beban bunga pinjaman yang lebih kecil dari pada sumber hutang yang lainnya serta ditunjang dengan peningkatan aset perusahaan, sehingga perusahaan sampel masih mampu untuk mengembalikan hutang-hutang yang dipinjamnya tanpa harus melakukan kecurangan pelaporan keuangan (Trisnaningsih, 2019). Selain itu manajemen perusahaan sampel lebih memilih untuk melakukan penerbitan saham yang bertujuan untuk memperoleh tambahan modal dari pada memilih untuk membuat perjanjian utang baru sehingga dapat mengurangi perusahaan sampel mengalami tekanan untuk membayar hutang yang dipinjamnya dikemudian hari, dan dapat mencegah tekanan yang dapat menimbulakan kecurangan pelaporan keuangan (Sulastri, 2019).

\section{Pengaruh Peluang Dalam Pendeteksian Kecurangan Pelaporan Keuangan}

Pada tabel 8 , nilai signifikansi variabel $\mathrm{X}_{2}$ sebesar $0,913>0,05$ dan nilai koefisien regresi sebesar 0,336 . Hasil ini sejalan dengan penelitian terdahulu yaitu oleh Setiawan (2018) yang menujukkan bahwa secara parsial frekuensi jumlah komite audit independen yang merupakan proksi variabel peluang tidak berpengaruh dalam pendeteksian kecurangan pelaporan keuangan.

Hal tersebut disebabkan walau adanya peningkatan atau penurunan jumlah anggota komite audit independen pada perusahaan sampel, tidak memberi pengaruh untuk melakukan kecurangan pelaporan keuangan. Keanggotaan komite audit pada perusahaan sampel berdasarkan Peraturan OJK No. 55 Tahun 2015 yang menyatakan bahwa perusahaan sampel harus memiliki minimal 3 orang anggota komite audit yang terdiri dari komisaris independen dan pihak luar perusahaan yang direkrut serta diberhentikan oleh dewan komisaris perusahaan. Ketua komite audit di perusahaan sampel haruslah dari komisaris independen serta mayoritas anggota dari pihak independen. Berdasarkan pemaparan diatas, dapat dikatakan bahwa pada susunan anggota komite audit perusahaan sampel haruslah pihak independen sehingga tidak berpengaruh dalam pendeteksian kecurangan pelaporan keuangan.

\section{Pengaruh Rasionalisasi dalam pendeteksian Kecurangan Pelaporan Keuangan}

Pada tabel 8, nilai signifikansi variabel $X_{3}$ sebesar 0,309 $>0,05$ dan nilai koefisien regresi sebesar - 0,938. Hasil ini sejalan dengan penelitian Agustina dan Pratomo (2019) yang menujukkan bahwa secara parsial pergantian akuntan publik yang merupakan proksi variabel rasionalisasi tidak berpengaruh dalam pendeteksian kecurangan pelaporan keuangan.

Hal tersebut dikarenakan perusahaan sampel yang melakukan pergantian akuntan publik bukan bertujuan untuk memperkecil kemungkinan terjadinya pendeteksian kecurangan pelaporan keuangan oleh akuntan publik yang lama, namun dikarenakan perusahaan sampel ingin mentaati peraturan pemerintah yang berlaku yakni PP RI No. 20 Tahun 2015 yang mengatakan bahwa Kantor Akuntan Publik saat melaksanakan audit di suatu entitas tidak lagi dibatasi. Pembatasan mengenai audit yang berlaku bagi akuntan publik yakni berurutan dalam kurun waktu lima tahun. Pergantian akuntan publik juga dapat terjadi dikarenakan akuntan publik sebelumnya tidak mampu untuk menyelesaikan audit laporan keuangan entitas atau bisa terjadi karena KAP serta akuntan publik sebelumnya memperoleh sanksi dari OJK yang dapat berpengaruh terhadap citra perusahaan.

\section{Pengaruh Kompetensi Dalam Pendeteksian Kecurangan Pelaporan Keuangan}

Pada tabel 8, nilai signifikansi variabel $\mathrm{X}_{4}$ sebesar $0,152>0,05 \mathrm{dn}$ nilai koefisien regresi sebesar - 1,634. Hasil ini sejalan dengan penelitian Agustina dan Pratomo (2019) 
yang menujukkan bahwa secara parsial pergantian direksi yang merupakan proksi variabel kompetensi tidak berpengaruh dalam pendeteksian kecurangan pelaporan keuangan.

Hal tersebut dikarenakan perusahaan sampel yang melakukan pergantian direksi bukan bertujuan untuk melakukan kecurangan pelaporan keuangan. Alasan perusahaan sampel yang berkaitan dengan pergantian direksi sudah dijelaskan pada laporan tahunan masing-masing perusahaan sampel. Berdasarkan PP RI No. 45 Tahun 2005 menyatakan bahwa jabatan anggota dewan direksi akan berakhir apabila; (1) Masa jabatannya telah berakhir. (2) Diberhentikan berdasarkan keputusan Rapat Umum Pemegang Saham/Mentri. (3) Tidak memenuhi persyaratan sebagai anggota direksi berdasarkan kententuan peraturan pemerintah serta peraturan perundang-undangan lainnnya. (4) Meninggal Dunia. Berdasarkan hal tersebut, pergantian direksi yang dilakukan oleh perusahaan bukan terjadi karena kecurangan pelaporan keuangan (Bawekes, 2018).

\section{Pengaruh Arogansi Dalam Pendeteksian Kecurangan Pelaporan Keuangan}

Pada tabel 8, nilai signifikansi variabel $\mathrm{X}_{5}$ sebesar $0,031<0,05$ dan nilai koefisien regresi sebesar 0,613. Hasil ini sejalan dengan penelitian Tessa dan Harto (2016) yang menujukkan bahwa secara parsial frekuensi jumlah foto CEO yang merupakan proksi variabel arogansi yang berpengaruh positif signifikan dalam pendeteksian kecurangan pelaporan keuangan.

Dari hasil penelitian ini dapat dikatakan bahwa secara parsial frekuensi jumlah foto CEO yang merupakan proksi variabel arogans berpengaruh positif signifikan dalam pendeteksian kecurangan pelaporan keuangan di perusahaan sampel. Rata-rata banyaknya foto CEO yang tercantum pada laporan tahunan perusahaan sampel adalah 9,46 atau jika dibulatkan menjadi 10, sedangkan nilai maksimum jumlah foto CEO sebanyak 15 buah, dapat dikatakan bahwa semakin banyak jumlah foto CEO yang tercantum di laporan tahunan perusahaan sampel maka CEO terindikasi mempunyai sifat arogansi yang semakin tinggi. CEO yang mempunyai sifat arogansi yang tinggi menyebabkan fraudulent financial reporting dapat terjadi, hal ini dikarenakan CEO perusahaan sampel yang mempunyai sifat arogansi serta superioritas yang tinggi merasa bahwa control internal apapun tidak akan memberikan dampak padanya, dikarenakan status serta posisi yang dimiliknya (Tessa dan Harto, 2016). Semakin tinggi sifat arogansi yang dimiliki oleh CEO perusahaan juga dapat mendorong CEO perusahaan untuk melaksanakan bermacam cara guna untuk melindungi jabatan serta status yang dimilikinya (Crowe, 2011).

\section{Pengaruh Tekanan, Peluang, Rasionalisasi, Kompetensi dan Arogansi Terhadap Kecurangan Pelaporan Keuangan}

Pada tabel 8, nilai signifikansi variabel $X_{1}, X_{2}, X_{3}, X_{4}, X_{5}$ sebesar $p$ value Chi Square sebesar 0,005 $<0,05$. Hasil ini sejalan dengan penelitian Agustina dan Pratomo (2019) yang menujukkan bahwa secara simultan variabel tekanan, peluang, rasionalisasi, kompetensi dan arogansi berpengaruh signifikan dalam pendeteksian kecurangan pelaporan keuangan.

Dari hasil penelitian ini dapat dikatakan bahwa secara simultan atau bersama-sama variabel tekanan, peluang, rasionalisasi, kompetensi dan arogansi berpengaruh signifikan dalam pendeteksian kecurangan pelaporan keuangan, yang artinya kelima variabel tersebut merupakan faktor penyebab perusahaan melakukan kecurangan pada teori pentagon fraud dapat dipakai dalam pendeteksian kecurangan pelaporan keuangan pada BUMN yang terdaftar di BEl.

\section{Simpulan Dan Saran}

Simpulan penelitian ini adalah, pertama, Rasio leverage yang menjadi proksi variabel tekanan berpengaruh negatif signifikan, sedangkan frekuensi jumlah foto CEO yang menjadi proksi variabel arogansi berpengaruh postif signifikan dalam pendeteksian kecurangan pelaporan keuangan pada BUMN yang terdaftar di BEI. Untuk persentase jumlah komite audit independen yang menjadi proksi variabel peluang, pergantian akuntan publik yang menjadi proksi variabel rasionalisasi, dan pergantian direksi yang menjadi proksi variabel kompetensi tidak berpengaruh dalam pendeteksian kecurangan pelaporan keuangan pada 
BUMN yang terdaftar di BEl. Kedua, Secara simultan variabel tekanan, peluang, rasionalisasi, kompetensi dan arogansi berpengaruh signifikan dalam pendeteksian kecurangan pelaporan keungan pada BUMN yang terdaftar di Bursa Efek Indonesia.

Peneliti memberikan saran yaitu, pertama, untuk perusahaan/ Badan usaha dalam menyusun laporan keuangan serta laporan tahunan BUMN harus lebih memperhatikan faktor apa saja yang berpengaruh dalam pendeteksian kecurangan pelaporan keuangan. Berdasarkan hasil penelitian, faktor yang harus diperhatikan oleh BUMN adalah faktor arogansi berupa frekuensi jumlah foto CEO. Kedua, untuk Stakeholder diharapkan dapat selektif dalam memilih tempat untuk berinvestasi sehingga tidak salah pada saat pengambilan keputusan untuk berinvestasi di perusahaan yang melaksanakan praktik kecurangan pelaporan keuangan. Pertimbangan yang bisa diambil dari penelitian ini adalah frekuensi jumlah foto CEO yang merupakan variabel arogansi berpengaruh positif signifikan dalam pendeteksian kecurangan pelaporan keuangan. Ketiga, penelitian berikutnya dapat memilih salah satu sektor jangan menggabungkannya menjadi satu serta menggunakan lebih dari satu proksi untuk mewakilkan variabel independen. Dengan demikian hasil penelitian yang diperoleh dapat lebih mewakili untuk diambil kesimpulannya.

\section{Daftar Pustaka}

Agustina, R. D. dan D. Pratomo. 2019. "Pengaruh Fraud Pentagon Dalam Mendeteksi Kecurangan Pelaporan Keuangan (Studi Pada Perusahaan Sektor Pertambangan Yang Terdaftar Di Bursa Efek Indonesia Periode 2013-2017)". Jurnal Stiemb. Vol. 3 No. 1.

Ak., B. K., P. M. Dechow, Y. Sun, and A. Y. Wang. 2013. "The Use of Financial Ratio Models to Help Investors Predict and Interpret Significant Corporate Events". Elsevier SSRN Paper, 1-74.

Alwi, M., K. A. Kamarudin and W. A W. Ismail. 2014. "The Effects of Audit Committee Attributes on Fraudulent Financial Reporting". Journal of Modern Accounting and Auditing. Vol. 10 No. 5.

Annisya, M., Lindrianasari, dan Y. Asmaranti. 2016. "Pendeteksian Kecurangan Laporan Keuangan Menggunakan Fraud Diamond". Jurnal Bisnis dan Ekonomi. Vol. 23 No.1.

Aprilia. 2018. "Analisis Pengaruh Fraud Pentagon terhadap Kecurangan Laporan Keuangan dengan Menggunakan Beneish Model pada Perusahaan yang Menerapkan Asean Corporate Governace Scorecard". Jurnal Aset (Akuntansi Riset). Vol. 9 No. 1.

Association of Certified Fraud Examiners. 2016. "Survai Fraud Indonesia". Diakses pada tanggal 1 Februari 2020 web: https://acfe-indonesia.or.id/survei-fraud-indonesia/

Bawekes, H. F. 2018. "Pengujian Teori Fraud Pentagon Terhadap Fraudulent Financial Reporting". Jurnal Akuntansi dan Keuangan Daerah. Vol. 13. No. 1.

Crowe, H. 2011. The Mind Behind The Fraudsters Crime: Key Behaviorial and Environtmental Element.

Harahap, D. A. T., Majidah, dan Triyanto, D. N. 2017. "Pengujian Fraud Diamond Dalam Kecurangan Laporan Keuangan (Studi Kasus Pada Perusahaan Pertambangan yang terdaftar di Bursa Efek Indonesia Tahun 2011-2015)". E-Proceeding of Management.Vol. 4. No. 1.

Hartomo, G. 2019. "Kronologi Kasus Laporan Keuangan Garuda Indonesia Hingga Kena Sanksi". Diakses pada tanggal 1 Februari 2020. Web : https://www.economy.okezone.com/amp/2019/28/320/2072245/kronologi-kasuslaporan-keuangan-garuda-indonesia-hingga-kena-sanksi?page=3

Kementrian BUMN. 2020. Diakses tanggal 1 Februari 2020. Web : https://bumn.go.id/halaman/saham 
Manurung, D. T.H dan A. Hardika. 2015. "Analysis Of Factors That Influence Financial Statement Fraud In The Perspective Fraud Diamond: Empirical Study On Banking Company Listed On The Indonesia Stock Exchange Year 2012". International Confrence On Accounting Studies (ICAS)

Marks, J. 2012. The Mind Behind The Fraudsters Crime: Key Behavioral And Environmental Elements. Crowe Howarth LLP (Presentation).

Noorjamil, K. 2019. "Pengaruh Fraud Pentagon Terhadap Kecurangan Laporan Keuangan (Fraudulent Financial Statement) (Studi Empiris Pada Perusahaan Sektor Pertambangan Yang Terdaftardi Bursa Efek Indonesia Periode 2015-2017)”. Vol 5 no 1.

OJK, Peraturan Otoritas Jasa Keuangan No. 55 Tahun 2015 tentang Pembentukan Dan Pedoman Kerja Komite Audit.

Public Company Accounting Oversight Board. 2017. Auditing Standards. Washing ton: PCAOB.

Republik Indonesia. Peraturan Pemerintah Republik Indonesia No 20 Tahun 2015 Tetang Praktik Akuntan Publik.

Republik Indonesia. Peraturan Pemerintah Republik Indonesia No. 45 Tahun 2005 tentang Pendirian, Pengurus, Pengawasan dan Pembubaran Badan Usaha Milik Negara

Rusmana, O dan H. Tanjung. 2019. "Identifikasi Kecurangan Laporan Keuangan Dengan Fraud Pentagon Studi Empiris BUMN yang Terdaftar di Bursa Efek Indonesia”. Jurnal Ekonomi, Bisnis dan AKuntansi (JEBA). Vol. 21. No 4.

Septriani, Y. dan D. Handayani. 2018. "Mendeteksi Kecurangan Laporan Keuangan Dengan Analisis Fraud Pentagon”. Jurnal Akuntansi, Keuangan Dan Bisnis. Vol. 11. No. 1.

Siddiq, F. R., F. Achyani, Dan Zulfikar. 2017. "Fraud Pentagon Dalam Mendeteksi Financial Statement Fraud". Seminar Nasional dan The $4^{\text {th }}$ Call for Syariah Paper.

Sulastri, Nining. 2019. Analisis Fraud Triangle dan Ukuran Perusahaan Dalam Mendeteksi Potensi Kecurangan Laporan Keuangan (Studi pada Perusahaan Manufaktur yang Terdaftar di BEI Tahun 2014-2017). Skripsi. Jurusan Akuntansi S1. Universitas Islam Indonesia.

Tessa, C. G. dan P. Harto. 2016. "Fraudulent Financial Reporting: Pengujian Teori Fraud Pentagon Pada Sektor Keuangan Dan Perbankan Di Indonesia". Journal of Simposium Nasional Akuntansi XIX, Lampung.

Trisnaningsih. 2019. Analisis Kecurangan Pelaporan Keunagna Dengan Fraud Pentagon Pada Perusahaan Pertambangan Yang terdaftar DI BEI Tahun 2015-2017. Skripsi. Jurusan Akuntansi Syariah. Institut Agama Islam Negeri Surakarta.

Wardhani, L. K. 2018. Deteksi Fraudulent Financial Reporting Dengan Teori Fraud Pentagon Pada Sektor Keuangan Di Indonesia. Skripsi (tidak diterbitkan). STIE Perbanas Surabaya. 